\title{
Rola muzeum \\ w ochronie dziedzictwa kulturowego Tatarów polsko-litewskich
}

DOI: http://dx.doi.org/10.12775/LC.2016.023

Streszczenie. Muzeum Historyczne Oddział Muzeum Podlaskiego w Białymstoku posiadając w swoich zbiorach unikatową w skali kraju kolekcję pamiątek związanych z historycznym osadnictwem Tatarów na pograniczu Wielkiego Księstwa Litewskiego i Korony Polskiej, dokłada wszelkich starań, aby chronić tatariana i upowszechniać wiedzę o nich. Szczególnie cenne rękopiśmienne muzułmańskie księgi religijne - Korany i chamaiły (modlitewniki), kopiowane przez tatarskich wyznawców islamu, są przedmiotem badań filologicznych slawistów i arabistów. Muzeum pozyskuje także środki na ich konserwację, dzięki której są im przywracane walory czytelniczo-ekspozycyjne. Wcześniejsze inicjatywy utworzenia samodzielnego muzeum tatarskiego, przed II wojną światową w Wilnie czy w latach 70. XX w. w Sokółce, nie przyniosły zakładanych rezultatów. Zbiór tatarianów przekazany w 1979 r. do Muzeum Historycznego w Białymstoku, w następnych latach powiększany o kolejne dary i zakupy, był prezentowany na wielu czasowych ekspozycjach w polskich placówkach muzealnych. Charakter zabytków, wytworzonych najczęściej na papierze lub tkaninie, zobowiązuje opiekunów kolekcji do ich szczególnej ochrony przed działaniem szkodliwych czynników zewnętrznych: wilgocią, nadmiernym oświetleniem, zanieczyszczeniem. Współczesne techniki pozwalają na uzyskanie cyfrowego, jak najbardziej wiernego odwzorowania obiektów. Wszystkie tatariana zostały zdigitalizowane, co wraz z konserwacją zapewnia trwałe zachowanie tych tak ważnych dla historii i kultury Tatarów polsko-litewskich, ale także całego społeczeństwa polskiego, oryginalnych zabytków. Zostały one udostępnione wszystkim zainteresowanym, jako jedne z pierwszych, na stronie internetowej Muzeum Podlaskiego w Białymstoku w Muzeum Cyfrowym.

Słowa kluczowe: Muzeum Historyczne w Białymstoku, kolekcja „tatarianów”, Tatarzy Wielkiego Księstwa Litewskiego, kultura Tatarów polsko-litewskich

\footnotetext{
* Lucyna Lesisz - kierownik Muzeum Historycznego Oddziału Muzeum Podlaskiego w Białymstoku. E-mail: lucyna.I@wp.pl.
} 
Abstract. The Historical Museum, the Branch of Podlaskie Museum in Białystok, owning as a part of its holdings a collection - a unique one in national scale - of relics connected to the Tatar settlement on the borderlands of the Grand Duchy of Lithuania and the Polish Crown, makes every effort to preserve this heritage and popularize knowledge about it. Within the collection, the particularly valuable hand-written Muslim religious books - Korans and "chamaiłs" (prayer books) that were copied by the Tatar believers of Islam - are now the objects of philological research by both Slavists and Arabists. The museum also secures funds for the conservation of these relics, which allows to restore their reading and expositional qualities. Earlier attempts to establish a separate Tatar museum - before World War II, in Vilnius, or in the 1970s, in Sokółka - did not bring the expected outcomes. The collection of Tatar relics that was given to the Historical Museum in Bialystok in 1979, and in the following years expended by new gifts and purchases, has been presented at numerous temporary exhibitions in museums around Poland. The character of these historical objects, usually inscriptions on paper or fabric, demands careful preservation from the collection holders: it needs to be protected against damaging environmental factors such as humidity, too intense lighting, or pollution. Contemporary techniques allow scholars to make digital records of the objects, which are as faithful as possible. All the Tatar relics have been digitalized, which, together with their conservation, guarantees a long-time preservation of the original objects that are so important for the history and culture both of the Polish-Lithuanian Tatars, and the Polish society. They were among the first objects that were made available to the interested public through the website of the Podlaskie Museum in Białystok, within the framework of the Digital Museum project.

Keywords: The Historical Museum in Białystok, collection of "tatariana", Tatars of the Grand Duchy of Lithuania, culture of Polish-Lithuanian Tatars

stawa o muzeach definiuje:

Art. 1. Muzeum jest jednostką organizacyjną nienastawioną na osiąganie zysku, której celem jest gromadzenie i trwała ochrona dóbr naturalnego i kulturalnego dziedzictwa ludzkości o charakterze materialnym i niematerialnym, informowanie o wartościach i treściach gromadzonych zbiorów, upowszechnianie podstawowych wartości historii, nauki i kultury polskiej oraz światowej, kształtowanie wrażliwości poznawczej i estetycznej oraz umożliwianie korzystania ze zgromadzonych zbiorów ${ }^{1}$.

Pierwszym muzeum gromadzącym pamiątki z przeszłości tatarskich osadników na Litwie i w Polsce było Tatarskie Muzeum Narodowe w Wilnie założone przez Radę Centralną Związku Kulturalno-Oświatowego Tatarów RP w 1929 r. Funkcję jego kustosza pełnił Leon Kryczyński², tatarski historyk, prawnik, działacz społeczny, który włączył do

1 Art. 1 Ustawy z dnia 29 czerwca 2007 r. o zmianie ustawy o muzeach, Dz. U. z 2007 r. nr 136, poz. 956, z późn. $\mathrm{zm}$.

2 Leon Najman-Mirza Kryczyński herbu Radwan - urodzony 25 września 1887 r. w Wilnie, w rodzinie generała Konstantego Kryczyńskiego. W latach 1907-1911 studiował prawo na uniwersytecie w Petersburgu, gdzie założył koło studentów muzułmańskich, którego celem było zbieranie materiałów bibliograficznych do historii Tatarów litewsko-polskich. Uczestnik narodowo-wyzwoleńczych działań na Krymie i w Azerbejdżanie. 
zasobów muzealnych także swoje zbiory. Z braku samodzielnej siedziby ekspozycja została zorganizowana w lokalu Muftiatu. W kronice „Ateneum Wileńskiego” z 1930 r. odnotowano:

Tatarskie Muzeum Narodowe mieści się przy Zaułku Ś-to Michalskim 5. Na zbiory składają się 104 eksponaty, w tym wiele fotografii, rycin, sztychów przeważnie z okresu wojny światowej, kilka rękopisów Koranu z XVIII w. , dokumentów z XVI w. pisanych w języku białoruskim oraz 6 monet arabskich z XIII w. ${ }^{3}$

W wydanym katalogu wymieniono: rękopiśmienne Korany i kitaby4, zbiór dokumentów z pieczęciami tatarskimi, fotografie wojska tatarskiego w Polsce od czasów najdawniejszych, monety kufickie ${ }^{5}$, stare druki o Tatarach (m.in. Alfurkan Tatarski z 1616 r.), jeden dokument z XVIII w. z podpisem króla Stanisława Augusta, pamiątki po generale Macieju Sulkiewiczu, Aleksandrze Sulkiewiczu (Michale Czarnym), Stefanie Bielaku, po pułku tatarskim im. Mustafy Achmatowicza, rysunki i fotografie meczetów ${ }^{6}$.

W 1931 r. powstało archiwum przy oddziale wileńskim ZKOT RP, które posiadało w swych zbiorach przeszło 50 dokumentów z XVI i XVII w., pozostające również pod opieką Leona Kryczyńskiego 7 . W 1934 wyjechał on do Zamościa, a eksponaty z muzeum i dokumenty $\mathrm{z}$ archiwum, pozbawione opieki, zostały zmagazynowane $\mathrm{w}$ siedzibie Muftiatu. Pozostały tam do wybuchu wojny. Ich losy nadal pozostają nieznane ${ }^{8}$.

Takie były początki tatarskiego muzealnictwa w Polsce. Ta wspaniała inicjatywa, niemająca jednak instytucjonalnego wsparcia i właściwych zabezpieczeń, paradoksalnie przyczyniła się do utraty wielu cennych dokumentów mówiących o historii Tatarów w Rzeczypospolitej Obojga Narodów, aż po pierwsze lata po odzyskaniu przez Polskę niepodległości.

Wojna spustoszyła środowisko inteligencji tatarskiej. W latach 60. XX w. Maciej Konopacki ${ }^{9}$ podjął wysiłek przywrócenia tożsamości etnicznej Tatarów, z którymi łączyły go wspólne korzenie. Na początku lat 70 . XX w. odżył projekt utworzenia muzeum tatar-

Szef kancelarii premiera rządu Krymskiej Republiki Ludowej w latach 1918-1919. Dyrektor kancelarii rządu Azerbejdżańskiej Republiki Demokratycznej w latach 1919-1920. W okresie międzywojennym pracował jako prawnik w Wilnie, Zamościu i Gdyni. Członek Polskiego Towarzystwa Orientalistycznego od 1930 r. Organizator Narodowego Muzeum Tatarskiego w Wilnie. W latach 1932-1938 redaktor naczelny wydawnictwa naukowego „Rocznik Tatarski”. 27 września 1939 r. został aresztowany przez Gestapo i rozstrzelany między październikiem 1939 a kwietniem 1940 r. w Piaśnicy koło Wejherowa. Na podst.: S. Dumin, A. Jakubauskas, G. Sitdykow, Tatarskie biografie. Tatarzy polsko-litewscy w historii i kulturze, Białystok 2012, s. 98-100.

3 "Ateneum Wileńskie” 1930, r. VII, z. 1/2, s. 409.

4 Kitab (ar. kitāb „książka”, ,księga”) - księga o zróżnicowanej treści, mająca charakter kodeksu. Zbiór tekstów zawierających zasady religii muzułmańskiej, opowieści moralistyczne związane z treścią Koranu, przepisy rytualne, legendy z życia proroków, apokryfy, tłumaczenia lub oryginały modlitw. Kitab stanowił podstawowy nośnik literatury i wiedzy religijnej Tatarów. Szerzej na ten temat zob. A. Drozd, M. Dziekan, T. Majda, Katalog Zabytków Tatarskich, t. 3: Piśmiennictwo i muhiry Tatarów polsko-litewskich, Warszawa 2000, s. 13.

5 Monetami kufickimi nazywano najstarsze numizmaty arabskie. Nazwa pochodzi od występującego na nich pisma kufickiego, najstarszej formy kaligrafii arabskiej charakteryzującej się kątami prostymi, stąd termin „pismo kwadratowe". Stosowano tę formę w najstarszych egzemplarzach Koranu, a także ze względu na jej monumentalny charakter w inskrypcjach na ścianach meczetów. Por. D. Malarczyk, Między Wschodem a Zachodem. Od Damaszku do Andaluzji. Pieniądz islamski w wiekach średnich, Kraków 2015.

6 A. Miśkiewicz, Tatarzy polscy 1918-1939, Warszawa 1990, s. 111.

7 "Rocznik Tatarski” 1932, t. I, s. 331.

8 A. Miśkiewicz, op. cit., s. 181.

9 Maciej Musa Konopacki - życie i dzieło zob. w dziale Mistrzowie w tym tomie. 
skiego. Jak pisze Rafał Berger, był to wspólny pomysł Macieja Konopackiego i Mahmuda Tahy Żuka ${ }^{10}$.

Muzeum poświęcone historii i kulturze Tatarów polsko-litewskich miało być utworzone w Sokółce. Lokalizacja wiązała się z bliskim położeniem wsi tatarskich z nadań króla Jana III Sobieskiego, a także jedynych dwóch meczetów - w Bohonikach i Kruszynianach, które pozostały w Polsce po zmianie granic w 1945 r. ${ }^{11}$ Projekt spotkał się z bardzo dużą przychylnością i pomocą ze strony polskiego i zagranicznego środowiska orientalistycznego oraz historyków. Nie brakowało też sceptycznych opinii, związanych głównie ze statusem takiej placówki.

Maciej Konopacki z dużym zaangażowaniem przystąpił do pracy przy tworzeniu muzeum pielęgnującego przeszłość „polskiego Orientu”. Przede wszystkim popularyzował ideę nowej placówki. Na łamach prasy opublikował wiele artykułów poświęconych zabytkom związanym z osadnictwem tatarskim. Zgromadzone wówczas eksponaty miały być prezentowane w dziale tatarskim muzeum regionalnego w Sokółce. Ale w latach 70. XX w. placówka ta nie spełniała warunków, w jakich powinny być przechowywane i eksponowane szczególnie wrażliwe zabytki. Zebrane obiekty w 1979 r. zostały przekazane do działu historycznego Muzeum Okręgowego w Białymstoku i dały początek kolekcji nazywanej „tatarianami”. Nadal stanowią jej trzon.W kolejnych latach zbiór powiększano o nowe eksponaty gromadzone poprzez dary i zakupy.

Prawo litewskie uznawało tatarskich ziemian służących w wojsku za szlachtę, przyznając im podstawowe przywileje sądowe i majątkowe tego stanu, z pewnymi ograniczeniami związanymi z wyznawaną przez nich niechrześcijańską religią. Na przestrzeni wieków Tatarzy, pozbawieni przedstawicieli w sejmie, swoje równouprawnienie z resztą szlachty w Rzeczypospolitej Obojga Narodów zdobywali stopniowo i tylko do pewnego etapu. Po rozbiorach ukazy carów rosyjskich początkowo zatwierdzały przywileje królów polskich dla Tatarów ziemian. Ale później obejmował ich obowiązek wylegitymowania się przed Heroldią w Petersburgu, tak jak pozostałą szlachtę polską. Rejestrację szlachty ziemiańskiej powierzono marszałkom powiatu.

W kolekcji „tatarianów” znajdują się trzy dokumenty weryfikujące szlachectwo Tatarów:

1. Świadectwo potwierdzające nadanie tytułów szlacheckich przez króla Augusta II w 1698 r. tatarskim rodom Aleksandrowiczów, Szabanowiczów, Daniłowiczów i Rafałowiczów, wydane 13 maja 1821 r. przez Marszałka Powiatu Oszmiańskiego Kazimierza Czechowicza (MBHD/1258);

2. Wywód szlachectwa tatarskiej rodziny Bayraszewskich herbu Nowina - wypis z Ksiąg byłego Sądu Ziemskiego Powiatu Słonimskiego, wydane 11 sierpnia 1823 r. przez Marszałka Powiatu Wileńskiego Mikołaja Abramowicza (MBHD/1643);

3. Świadectwo wystawione 21 listopada 1841 r. przez urząd Heroldii Królestwa Polskiego potwierdzające szlachectwo Tatara Amurata Józefowicza herbu Radwan, dziedzica dóbr Lebiedziowa [Lebiedziew] i Małaszewicz Małych w Guberni Podlaskiej, nadane w 1790 r. (MBH/D/1800).

\footnotetext{
10 Profesorowie do Macieja, red. R. Berger, Warszawa 2015, s. 22.

11 W granicach II Rzeczypospolitej znajdowało się 17 meczetów.
} 


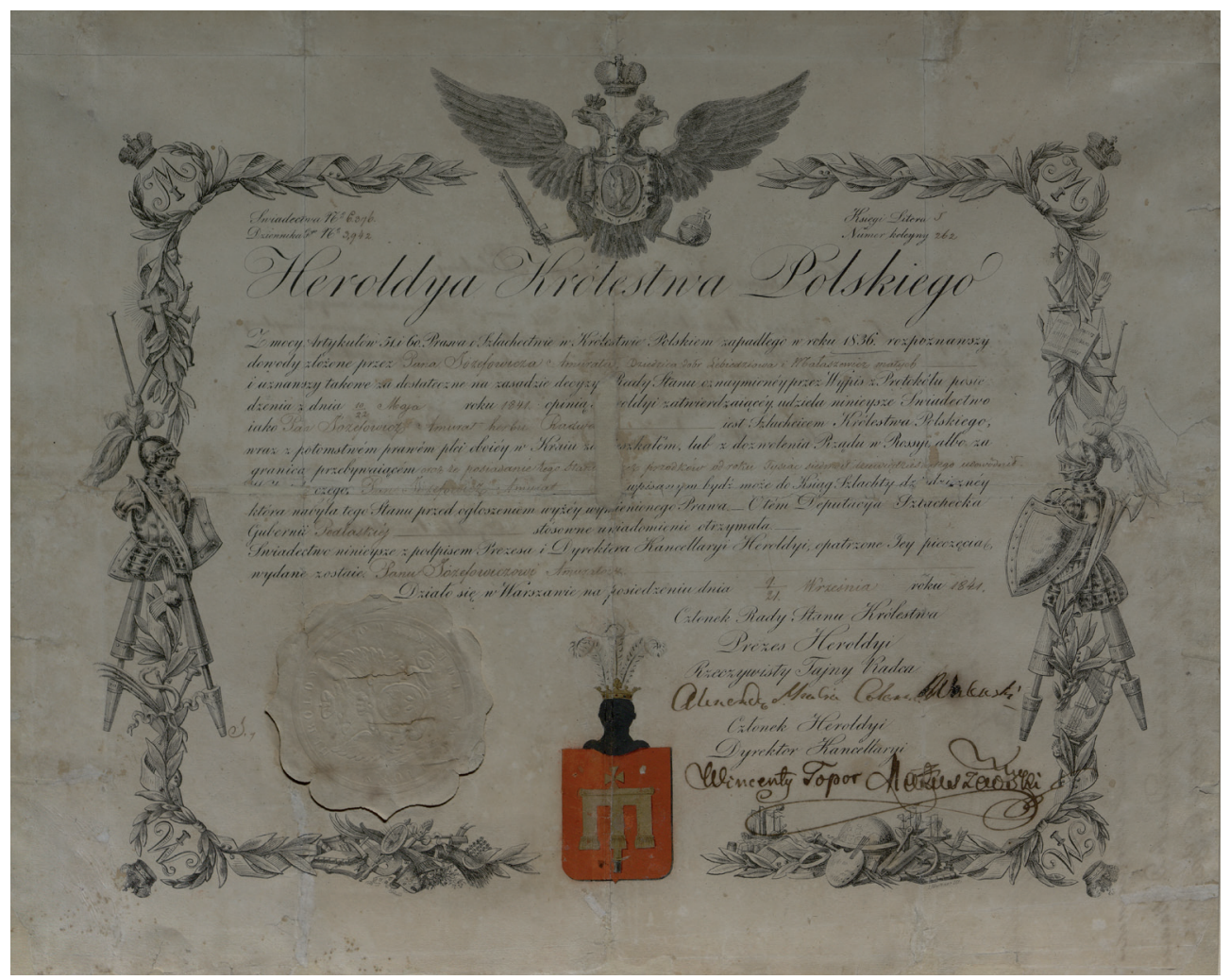

Fot. 1. Świadectwo urzędu Heroldii Królestwa Polskiego potwierdzające szlachectwo

Amurata Józefowicza herbu Radwan, 1841 r. (zbiory Muzeum Historycznego w Białymstoku, $\mathrm{MBH} / \mathrm{D} / 1800$, fot. K. Besztak)

Najcenniejsze eksponaty mają charakter religijny i są związane z islamem, który Tatarzy mieli prawo zachować po osiedleniu się na ziemiach Wielkiego Księstwa Litewskiego ${ }^{12}$. Swoją odrębność etniczno-kulturową Tatarzy polsko-litewscy utrzymali głównie dzięki kultywowaniu wyznania muzułmańskiego. W kolekcji znajdują się rękopiśmienne Korany, chamaiły ${ }^{13}$, barwne muhiry ${ }^{14}$ wykonane przez Tatarów oraz talizmany.

Mieszkając z dala od głównych ośrodków muzułmańskich, Tatarzy kopiowali świętą Księgę islamu i tworzyli własne modlitewniki (chamaiły), dla zachowania tradycyjnego, religijnego obrządku. Korany zawierały pełny tekst świętej Księgi w języku oryginału, tj. arabskim. Modlitwy, objaśnienia zasad recytacji oraz intencje, w których należało recytować koraniczne sury i wersety, umieszczano na pierwszych i ostatnich kartach. W innych manuskryptach oprócz języka arabskiego znajdowały się treści pisane po turecku i w językach słowiańskich - polskim i białoruskim, również napisane alfabetem arabskim w wersjach

12 Tatarzy przyjęli sunnicką wersję islamu w XIV w.

13 Chamaił (ar. ḥamā'il - „to, co się nosi przy sobie”) - osobiste amulety noszone przez muzułmanów w specjalnych woreczkach, zwykle na piersi. Stąd u muzułmanów polskich nazwa modlitewnika - chamaił. Por. J. Danecki, Kultura islamu. Słownik, Warszawa 1997, s. 81.

14 Muhir - ozdobna plansza lub tkanina z widokiem świętych miejsc czy przedmiotów islamu i wykaligrafowanym lub wyszytym wersetem z Koranu lub modlitwą. Zwykle oprawiona w ramę, była zawieszana w meczecie lub w domu, gdzie spełniała funkcję ochronną. 
przystosowanych do poszczególnych języków. Tłumaczenia wersetów koranicznych na języki miejscowe, dopuszczalne tylko jako objaśnienia, umieszczano interlinearnie między wierszami oryginalnego tekstu.

Rodzajem piśmiennictwa kitabowego ${ }^{15} \mathrm{w}$ zbiorach Muzeum Historycznego są chamaiły - modlitewniki zawierające opisy rytuałów muzułmańskich związanych z modlitwą, ablucją, nadaniem imienia, ślubem czy pogrzebem. Zawierają także teksty dewocyjne i tablice z kalendarzem muzułmańskim. Chamaił to przede wszystkim osobisty modlitewnik przeznaczony do codziennego użytku muzułmanina. Taki typ rękopiśmiennej księgi był najbardziej powszechny wśród Tatarów polsko-litewskich. Do dzisiaj wiele rodzin tatarskich posiada chamaiły, często przekazywane z pokolenia na pokolenie.

Wśród Tatarów funkcjonowały również chamaiły fałdżejskie ${ }^{16}$ przeznaczone dla osób parających się magią. Poza treściami właściwymi dla takich ksiąg, zamieszczano w nich także wróżby, senniki, formuły magiczno-lecznicze, zestawienia feralnych lub szczęśliwych liczb, dni i godzin oraz czynności. Wiedzę niezbędną do ich interpretacji posiadały tylko nieliczne, wtajemniczone osoby.

Na tą część kolekcji składają się:

1. Koran, 1824 r., kopista Mustafa Półtorzycki, 321 kart, 18,0 x 14,0 cm. Wszystkie sury Koranu są pisane jednym charakterem pisma, na takim samym czerpanym papierze, $\mathrm{z}$ wyjątkiem karty 1 recto oraz kart 318 do 321, które zostały dołączone do bloku księgi później. Na pierwszej karcie verso zostały zamieszczone nijety (intencje) zapisane alfabetem arabskim po turecku. Właściwa treść Koranu znajduje się na kartach od 1 do 317. Pierwsza sura Koranu Al-Fatiha („Otwierająca”) na karcie 1 recto została ozdobiona prostą iluminacją w postaci czarno-fioletowej potrójnej ramki zwieńczonej trójkątem (schematyczne przedstawienie kopuły meczetu). Iluminacja obejmuje także kartę 2 verso z pierwszymi ajatami (wersetami) II sury „Krowa”. Karta 318 verso zawiera modlitwy na zakończenie Koranu, kolejne - modlitwy arabskie, 320 - rozdział „Jeśli usłyszysz Azan”, a na 321 recto znajdują się krótkie objaśnienia niektórych reguł czytania Koranu. Na 321 karcie verso widnieje kolofon w języku polskim napisany alfabetem arabskim: „Pisałem ten świenty Kur’an tysionc osimset dwudziestego czwartego roku od narodzenia ^isi [Jezusa], / ^elejhi-ś-śelam [pokój z nim] w Maluszycach. Mustafa Półtoricki”'17 (MBH/1121);

2. Koran, XIX w., 265 kart, $21,5 \times 15,5 \mathrm{~cm}$. Na pierwszych trzech stronach został zamieszczony tekst polsko-białoruski z formułami arabskimi, dotyczący praktyki modlitewnej. Tekst Koranu na wszystkich stronach jest obwiedziony czerwoną ramką. Na karcie 264 recto znajduje się modlitwa arabska, a na 265 recto wpisano datę cyrylicą „1896 roku 19 dnia czerwca"18 (MBH/1126);

3. Koran, XIX/XX w., 158 kart, 21 x 16 cm. Rękopis niedokończony, zawiera jedynie $20 \operatorname{sur}(\mathrm{MBH} / 1128)$;

\footnotetext{
15 Piśmiennictwo kitabowe - dawne, tradycyjne piśmiennictwo religijne (od najbardziej reprezentatywnego typu rękopisu - kitabu). Szerzej zob. A. Drozd, M. Dziekan, T. Majda, op. cit., s. 12.

${ }^{16}$ Chamaiły fałdżejskie, czyli wróżbiarskie (tur. fałdży, arab. fa'l - „wróżba”, , przepowiednia”, „prognostyk”, z tur. końcówką określającą zawód). Por. S. Kryczyński, Tatarzy litewscy. Próba monografii historyczno-etnograficznej, „Rocznik Tatarski” 1938, t. 3, s. 250.

17 Tłumaczenie i transliteracja T. Majdy.

181896 goda ijunia 19 dnia.
} 
4. Chamaił, XIX w., kopista Sulejman Radecki, 271 kart, 16,0 x 10,0 cm. Treść modlitewnika nie jest uporządkowana, a całość składa się z kilku części połączonych w jeden blok książki, bez zachowania chronologii tworzenia poszczególnych składek. Papier różnego rodzaju, a teksty częściowo wyblakłe i nieczytelne. Najstarsze karty (40-55) pochodzą z 1. pol. XIX w. Pisany był przez kilku kopistów o różnych kompetencjach, spośród których zidentyfikowany jest tylko Sulejman Radecki z Jasionówki. Manuskrypt został spisany alfabetem arabskim w językach arabskim, tureckim, polskim i białoruskim. Treść bardzo różnorodna, na którą składa się kilka sur Koranu oraz wiele tekstów modlitewnych w języku arabskim i tureckim z objaśnieniami w języku polskim lub białoruskim zapisanych interlinearnie. Ta forma komentarza miała na celu wyjaśnienie wyznawcom islamu mieszkającym na pograniczu polsko-litewskim treści zawartych w oryginale arabskim lub tureckim w języku dla nich zrozumiałym ${ }^{19}$. Są $\mathrm{w}$ nim również zamieszczone kazania na święta i kolejne miesiące, szahada (muzułmańskie wyznanie wiary) ${ }^{20}$, epitety Allaha („99 świętych imion Boga”), opowieść o Proroku w języku arabskim, odpowiedzi na pytania o muzułmańskie terminy religijne (po białorusku), a także opowieści o ferejach (złych duchach).

W chamaile zapisano wiele tekstów fałdżejskich. Znajdują się w nim liczne przepisy magiczno-lecznicze ze wzorami amuletów i nusek ${ }^{21}$, modlitwy z zaklęciami do leczenia chorób psychicznych, formuly magiczne służące do prognozowania przebiegu leczenia, tablice cyfr „szczęśliwych”. Zamieszczono także słowniczek i zdania tureckie z polskim tłumaczeniem. Cztery karty, włączone do księgi, wykonano z jasnoniebieskiego papieru. Na pierwszej z nich znajduje się tabela z tabliczką mnożenia, na pozostałych tłumaczenie psalmów po polsku alfabetem arabskim. Chamaił należał do muezina ${ }^{22}$ Alego Asanowicza z Jasionówki (MBHD/1256).

Rękopis, jako najbogatszy w różnorodne treści spośród manuskryptów w kolekcji tatarianów, był szczegółowo opracowany w 1980 r. przez Tadeusza Majdę z Zakładu Turkologii Uniwersytetu Warszawskiego ${ }^{23}$. Znalazł się także w trzecim tomie Katalogu Zabytków Tatarskich $^{24}$ oraz był tematem pracy doktorskiej Iwony Radziszewskiej, obronionej na Uniwersytecie Mikołaja Kopernika w Toruniu ${ }^{25}$.

5. Chamaił, XIX w., kopista Józef Safarewicz, 186 kart, 17,0 x 11,0 cm. Na jego treść składają się modlitwy w intencji zmarłych i odmawiane przy odwiedzaniu cmentarzy, sura Jasin (szczególnie popularna przy obrzędach pogrzebowych) oraz formuły intencyjne towarzyszące jej odmawianiu, opisy codziennego rytuału modlitewnego (ablucji) i obowiązkowych pięciu modlitw rytualnych, modlitwy na szczególne okazje, a także okolicznościo-

19 Klucz do raju. Księga Tatarów litewsko-polskich z XVIII wieku, przeł. i oprac. H. Jankowski, Cz. Łapicz, Warszawa 2000, s. 18.

20 Szahada (ar. šahāda) - wyznanie wiary o treści: „Nie ma boga, jak tylko Bóg, Muhammad jest posłańcem Boga". Koran, tłum. J. Bielawski, Warszawa 1986, s. 789.

21 Nuska (ar. nusha „rękopis", „,kopia”,,,egzemplarz") - kartka z wypisanymi formułkami arabskimi, którymi zamawia się różne choroby, np. obłąkanie, zawroty głowy, chorobę św. Walentego i inne. Zob. S. Kryczyński, op. cit., s. 252.

22 Muezzin (z tur. müezzin, z arab. mu 'adِdin) - mężczyzna pięciokrotnie w ciągu dnia wzywający wiernych do modlitwy.

${ }^{23}$ Dokumentacja w formie maszynopisu jest przechowywana w Muzeum Historycznym w Białymstoku.

24 A. Drozd, M. Dziekan, T. Majda, op. cit., s. 9, 57, il. 76.

25 I. Radziszewska, Chamaiły jako typ piśmiennictwa religijnego muzułmanów Wielkiego Księstwa Litewskiego (na podstawie słowiańskiej warstwy językowej), niepublikowana praca doktorska, napisana pod kierunkiem prof. Czesława Łapicza, obroniona w 2010 r., UMK, Toruń. 
we formuły modlitewne po arabsku z polsko-białoruskimi komentarzami. Całość napisana alfabetem arabskim, a komentarze w języku polskim lub białoruskim.

Został wykonany z dwóch rodzajów papieru. Karty 1-150 z jednego gatunku, zapisane jednym charakterem pisma. Na karcie 150 recto znajduje się napis po polsku alfabetem arabskim informujący, że autorem tej części księgi jest Józef Safarewicz, który tworzył ją w Nowogródku, a pracę ukończył 24 czerwca 1871 r. ${ }^{26}$ Karty 151-186 są starsze, wykonane z papieru grubszego, w innym odcieniu. Zostały dołączone z innego rękopisu i są pisane bardziej wyrobionym charakterem pisma $(\mathrm{MBH} / 1122)$;

6. Chamaił, XIX/XX w., 40 kart, 18,0 x 11,5 cm. Różni się od pozostałych użytym alfabetem. Modlitwy są transkrybowane cyrylicą ${ }^{27} \mathrm{z}$ języka arabskiego i tureckiego, a nazwy poszczególnych modlitw i intencje są zapisane cyrylicą po rosyjsku. Na pierwszej karcie recto widnieje napis cyrylicą: Zenona Aleksandrowicza / Kriczinskiego / uc. VI klasa / S.M.G. Zenon Kryczyński był uczniem Gimnazjum Męskiego w Słonimiu. Chamaił ma układ łaciński z paginacją na górnym marginesie i jest napisany jednym charakterem pisma przy użyciu czarnego i czerwonego atramentu. Brak twardej oprawy, zewnętrzne karty spełniają funkcję okładek (MBH/1120);

7. Chamaił, pocz. XIX w., 61 kart, 9,5 x 6,25 cm. Modlitewnik zachowany tylko w części. Zawiera przede wszystkim treści zapisane $\mathrm{w}$ językach orientalnych, $\mathrm{z}$ nielicznymi wprowadzeniami w języku polskim i białoruskim. Tekst na każdej stronie jest zamknięty w ozdobnej, trójkolorowej ramce (atrament brązowy, żólty i czerwony). W treści znajdują się: 99 imion Allaha, modlitwy na różne pory dnia, wspominanie Boga (rodzaj litanii), teśpich $^{28}$ - modlitwa pochwalna, zapewniająca zbawienie, świąteczna (miesiąca ramazan), modlitwy na cmentarzu i przy przechodzeniu koło cmentarza, modlitwa przy zapalaniu świecy, iman (wiara, wyznanie wiary), modlitwa 12 imamów, Ahdinam (przysięga), za proroka Muhammada, pokutna, po namazach, o opuszczonych namazach. Część tekstu na pierwszych i ostatnich kartach jest słabo lub zupełnie nieczytelna.

$\mathrm{Na}$ stronie 60 verso widnieją notatki właściciela manuskryptu w języku polskim: „Wstąpiłem wsłuźb[e] / u Ryżski Drago[ń] / ski Połk ${ }^{29} 1838$ rok[u] / M. Maia 24 dnia / awansowałem / na Oficera 1840 / roku M. [Jollii?] $27 \mathrm{~d}[$ nia] / na Porucznika 1843 roku $[\ldots] /[30$ ? $]$ dnia / Stefan S[obolewski $]^{30} /$ Anny $[\ldots] / 1845 \operatorname{rok}[\mathrm{u}]$ na Sztab $[\ldots] /[\ldots]$ Szwadron $[\ldots] /[\ldots]^{\prime 31}$.

Zabytek ma niewielki format w porównaniu z innymi chamaiłami. Został oprawiony w skórzaną okładkę z wytłoczonymi inicjałami: M. B. Do muzeum przekazała go wnuczka Konstantego Sulejmanowicza. Według jej relacji dziadek przywiózł modlitewnik z Wilna, skąd wyemigrował w 1945 r. Rodzina Sulejmanowiczów, jak również rodzina Stefana

\footnotetext{
26 Tłumaczenie T. Majdy.

27 Pierwsze chamaiły transkrybowane cyrylicą pojawiły się na początku 2. poł. XIX w. i powstawały do I wojny światowej. Zob. A. Drozd, M. Dziekan, T. Majda, op. cit., s. 24.

28 Teśpich (tur. tespih) - różaniec muzułmański składający się z trzech grup paciorków po 33, lub tylko z 33 paciorków, co odpowiada 99 „pięknym imionom Boga”, które wymawia się przesuwając paciorki. Por. J. Danecki, op. cit., s. 164.

2911 Ryski Pułk Dragonów stacjonował w Krzemieńcu i wchodził w skład 11 Korpusu Armijnego Rosyjskiej Armii Carskiej.

30 Stefan Sobolewski został dołączony do spisu szlachty w 1845 r., po uzyskaniu stopnia porucznika. Zob. S. Dumin, Herbarz rodzin tatarskich Wielkiego Księstwa Litewskiego, Gdańsk 2006, s. 100.

31 Opracowanie I. Radziszewskiej na zlecenie Muzeum Podlaskiego w Białymstoku, 2010 r. Pełna dokumentacja dostępna w Muzeum Historycznym.
} 
Sobolewskiego (prawdopodobnie pierwszego właściciela rękopisu), zostały opisane w herbarzu Stanisława Dziadulewicza jako rodziny z tradycjami wojskowymi $(\mathrm{MBH} / 4760)^{32}$.

8. Chamail, 1790-1791, 95 kart, 13,2 x 10,0 cm. Treść na każdej stronie zamknięta $\mathrm{w}$ ramce pogrubionej zielonym tuszem i złoceniami. Kartę 1 verso zdobi iluminacja w postaci stylizowanej kopuly meczetu pomalowanej zielonym tuszem. Na karcie 84 recto znajduje się informacja, że chamaił został napisany w 1205 hidżry (1790-1791 według kalendarza gregoriańskiego). Sygnowany pieczątką: im. L. MUCHLA ${ }^{33}$. Na karcie 94 verso umieszczono dedykację w języku polskim: „Dar od p. Z [... ] / dla im. Luta Muchli / na Mewlud $^{34}$ (w dn. 3/III.1977)”.

Manuskrypt zawiera teksty arabskie i osmańskie, nie występują w nim teksty słowiańskie, co wskazuje na pochodzenie krymskie bądź tureckie. Zastosowany jest również inny rodzaj kaligrafii niż używany przez kopistów z kręgu Tatarów polsko-litewskich. W treści:

1) fragmenty Koranu w języku arabskim;

2) utwór „Blask serc” w języku tureckim;

3) modlitwy ${ }^{35}$.

Oprawa typu wschodniego, orientalnego (typ kopertowy) (MBH/4994);

9. Chamail, XIX w., 195 kart, 17,0 x 11,0 cm. Tekst pisany w języku arabskim lub w językach słowiańskich alfabetem arabskim. Jest to chamaił molliński (mułła albo mołła to osoba wykształcona w nauce i prawie islamu, nauczyciel religijny), służący imamom do odprawiania obrzędów religijnych ${ }^{36}$.

Księga została przywieziona do Polski przez Sulejmana Safarewicza ${ }^{37} \mathrm{z}$ Iwia (dużego ośrodka osadnictwa tatarskiego, obecnie na Białorusi) ( $\mathrm{MBH} / 5120)$.

Manuskrypty z kolekcji „tatarianów” (poza chamaiłami MBH/1120 i MBH/4994) noszą cechy charakterystyczne dla tego rodzaju ksiąg. Są pisane alfabetem arabskim z komentarzami i tłumaczeniami w językach słowiańskich. Układ tekstu oraz następstwo stron są odwrotne niż w tradycji europejskiej, paginację stanowią reklamanty (wyrazy, ich części lub tylko pierwsze litery, od których zaczyna się tekst następnej strony) ${ }^{38}$, iluminacje, jeżeli występują, są bardzo skromne. Zastosowano w nich jeden styl pisma arabskiego - nashīi, mają podobny format oraz europejski sposób oprawy.

\footnotetext{
32 S. Dziadulewicz, Herbarz rodzin tatarskich, Wilno 1929, s. 302-305, 307-308.

33 Lut Muchla był imamem gminy muzułmańskiej w Skidlu, Dowbuciszkach, Niekraszuńcach, a od 1947 r. w Białymstoku.

${ }^{34}$ Mewlud Bajram - święto urodzin Mahometa.

35 Opracowanie M. Tarełka, Mińsk.

36 A. Drozd, M. Dziekan, T. Majda, op. cit., s. 13.

37 S. Safarewicz był imamem w Bohonikach w latach 1980-1989.

38 Klucz do raju, s. 10.
} 


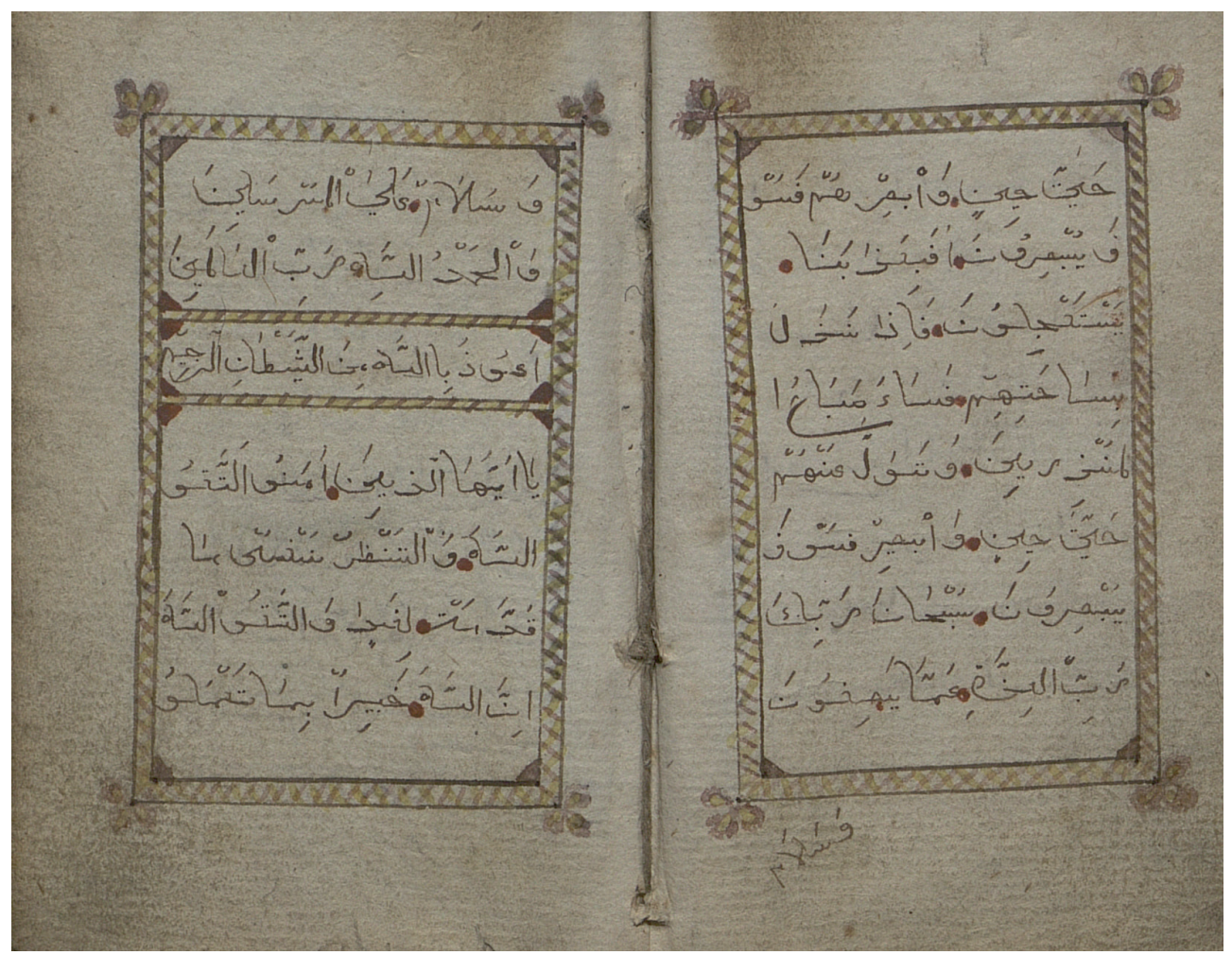

Fot. 2. Chamaił oficera 11 Ryskiego Pułku Dragonów (zbiory Muzeum Historycznego w Białymstoku, MBH/4760, fot. M. Węclaw)

W zbiorach „tatarianów” znajdują się także rękopiśmienne amulety pełniące funkcję ochronno-magiczną w religii Tatarów polsko-litewskich:

1. Daławar ${ }^{39}$, kopista Amurat Assanowicz, 1867 r., 571,0 x 7,5 cm. Brak początku. Zwój papierowy z modlitwami ochronnymi i zbawiennymi w języku arabskim i tureckim, tytuły niektórych modlitw w języku polskim. Tekst napisany jednostronnie i obwiedziony podwójną ramką. Wszystkie modlitwy są rozdzielone basmalą ${ }^{40}$. Na końcu, na stronie niezapisanej, znajduje się kolofon łacinką „1867 roku pisane przez Amurata Assanowicza Alekxandru Talkowskiemu. Na pamiątkę., a nad nim, napisany alfabetem arabskim, zapis własnościowy: „Jusuf syn Chalimy, jeśli Bóg pozwoli”41 (MBH/1104);

2. Nuska, XIX/XX w., 15,0 x 11,0 cm. Talizman z tekstem magicznym na łopatce baraniej z wypisaną czarnym tuszem kombinacją liter i cyfr arabskich, formuły: A'udu biĂllāhi ... i basmali w górnych rządkach. Tekst 112 sury Koranu tworzy prostokąt, w którego środku została umieszczona figura magiczna złożona $\mathrm{z}$ trzech przecinających się imion Muhammad.

\footnotetext{
39 Daławar (osm. duałar, ar. du 'ā’) - modlitwy. Zob. S. Kryczyński, op. cit., s. 213.

40 Basmala - muzułmańska formuła modlitewna „Bi-smi Allāhi ar-Rahmāni ar-Rahīmi” ("W imię Boga Miłosiernego, Litościwego"), od której zaczynają się wszystkie sury Koranu (z wyjątkiem 9) i którą prawowierny muzułmanin rozpoczyna każdą ważniejszą czynność. Por. J. Danecki, op. cit., s. 48.

41 A. Drozd, M. Dziekan , T. Majda, op. cit., s. 60, il. 91, 92.
} 
Pochodzi z terenu gminy muzułmańskiej w Bohonikach lub Kruszynianach. Do pisania nusek używano karteczek, więc przeznaczenie tak wykonanego amuletu, z otworem w górnej części, sugeruje, że mógł być zawieszany na szyi zwierzęcia ${ }^{42}(\mathrm{MBH} / 1546)$;

3. Hramotka ${ }^{43}$, XIX/XX w., 144,7 x 6,8 cm. Papierowy zwój z tekstem modlitw napisanym jednostronnie. Złożony w pakiecik o przybliżonych wymiarach $5,8 \times 6,8 \mathrm{~cm}$. Do zbiorów trafił w bardzo złym stanie zachowania. Papier mocno zdegradowany na skutek zawilgocenia, stąd rozpad na kilka części wzdłuż złożeń w pakiecik, z ubytkami. Brak czterech fragmentów - zostały zagubione lub całkowicie zniszczone. W zachowanym rękopisie treść jest podzielona na ponumerowane części (brak pierwszej, druga bez początku, dalej części od 3 do 12), na którą składają się wybrane ajaty z Koranu pisane w języku arabskim. Słowna numeracja części jest napisana alfabetem arabskim w języku słowiańskim. Na końcu zwoju widnieje zapis własnościowy: Ewa córka Zofii (MB/H/6099);

4. Nuska , 1. poł. XX w., 7,0 x 20,5 cm. Na wąskiej kartce z podłużnymi liniami, złożonej pionowo i podłużnie w ciasny pakiecik, jednostronnie została napisana duajka (modlitewka) składająca się z ajatów: 59-61 sury LIII „Gwiazda”, 9 sury XVIII „Grota”, 1-2 sury LXXXIV „Rozerwanie”, 1 sury XCIV „Otwarcie”, 4 sury XCIV „Otwarcie”, 2-3 sury XCIV „Otwarcie”, 4 sury XCIV „Otwarcie”, części ajatu 17 sury VIII „Łupy”, ajat 42 sury XXI „Prorocy”, 56 sury XXXIII „Frakcje”44 (MBH/6100);

5. Nuska - I pol. XX w., 7,0 x 7,0 cm. Na karteczce obustronnie napisana modlitwa w języku arabskim

Strona pierwsza:

1: uciekam się do Boga przed ukamienowanym szatanem

2: w imię Boga Miłosiernego Litościwego nie ma bóstwa

3: prócz Boga nie ma bóstwa prócz Boga nie ma bóstwa prócz

4: Boga Prorok Mahomet Mahomet

5: prorok Boga Mahomet nie nie

6: [tekst nieczytelny] nie nie nie

7: boga prócz nie [tekst nieczytelny]

8: [tekst nieczytelny]

9: Mahomet jest pośrednikiem Boga [tekst nieczytelny]

Strona druga:

1: w imię Boga Miłosiernego Litościwego nie ma mo-

2: cy ani siły jak tylko w Bo-

3: gu Najwyższym Nieskończonym

4: o [wyraz nieczytelny] o jedyny o Mahomecie

5: o Boże módl się za

6: Mahometa i ród Mahometa

7: oprócz Ciebie o Boże

8: o Panie ${ }^{45}$

42 Ibidem, s. 62, il. 101.

43 Hramotka (z brus. „pismo”, „pisemko”) - zwój z modlitwami ochronnymi noszony jako amulet przez osoby żyjące, złożony w pakiecik w skórzanym lub tekstylnym futeraliku i zawieszony pod prawym ramieniem. Dzieci otrzymywały hramotki przy azanie (uroczystość nadania imienia) w treści ograniczone do modlitewek ochronnych dla „dwunastu planet”, tj. znaków zodiaku i formułek chroniących zdrowie. Ibidem, s. 15.

44 Opracowanie M. Lewickiej, za: Koran, s. 636, 348-349, 716, 726, 212, 389, 508.

45 Tłumaczenie M. Lewickiej. 
Karteczka złożona poziomo i pionowo w pakiecik (MB/H/6102).

Pisma arabskiego Tatarzy używali także poza księgami religijnymi: w zdobnictwie sakralnym na muhirach, minbarach ${ }^{46}$ i suknach pogrzebowych oraz w inskrypcjach nagrobnych.

W kolekcji „tatarianów” muzeum posiada trzy rękopiśmienne muhiry:

1. Muhir z tablicami astrologicznymi, XIX w., gwasz na papierze, 78,0 x 57,0 cm. Kompozycja z „pieczęcią” w postaci 12 schodzących się centralnie okręgów, symbolizujących prawdopodobnie sfery niebios, umieszczona w otoczeniu gwiazd (?) ukazanych $\mathrm{w}$ formie 13 rozmieszczonych nieregularnie, wielopłatowych rozet. W ramki wzdłuż boków muhiru został wpisany komentarz polsko-białoruski z wtrętami tureckimi, w większości wytarty i nieczytelny. W ramce wzdłuż prawej krawędzi znajduje się tekst modlitewny w języku arabskim. W okręgach „pieczęci” prawdopodobnie także był wpisany modlitewny tekst w języku arabskim, a w środkowych polach rozet były umieszczone imiona proroków. Zabytek unikatowy na tle innych muhirów polsko-tatarskich, łączy symbolikę kosmologiczną z funkcją magiczną amuletu ${ }^{47}$. Został odnaleziony w latach $70 . \mathrm{XX}$ w. na strychu meczetu w Bohonikach. Autor nieznany, ale przypuszcza się, że powstał w środowisku Tatarów polsko-litewskich $(\mathrm{MBH} / 1107)$;

2. Muhir, 1854 r., 32,0 x 24,0 cm. Przedstawia zarys meczetu z kopułą i dwoma minaretami z wypisanymi modlitwami $\mathrm{w}$ języku arabskim oraz komentarzem polsko- białoruskim zapisanym alfabetem arabskim. Na odwrocie zapis darczyńcy: „Ten mugir pisany przez mego ojca Dawida Mucharskiego w roku 1854 w m. Kazaniu n / Wołgą. Dar od Mucharskiego Józefa m. Gołdap, dn. 16.VII-1975 r." ${ }^{\text {. }}$. Wykonany farbami wodnymi w kolorach zielonym, fioletowym, żółtym, różowym i błękitnym, a inskrypcje zostały napisane atramentem brązowym i czerwonym $(\mathrm{MBH} / 1115)$;

3. Muhir, lata 20.-30. XX w., 36,0 x 45,0 cm. Został wykonany techniką reliefu na desce obciągniętej niebieską satyną, z umieszczoną na niej szahadą, której litery wycięto z drewna i naklejono na tkaninę. U góry znajdują się dwa półksiężyce z gwiazdą, a w narożnikach ornamenty roślinne. W okresie międzywojennym taki wzór muhiru był rozprowadzany przez Muftiat (MBH/1114).

46 Minbar - kazalnica w meczecie służąca do wygłaszania uroczystych obwieszczeń, przemówień i kazań pod czas piątkowych modłów. Zob. J. Danecki, op. cit., s. 138.

47 A. Drozd, M. Dziekan, T. Majda, op. cit., s. 67 , il. 118.

48 Ibidem, s. 75, il. 154. 


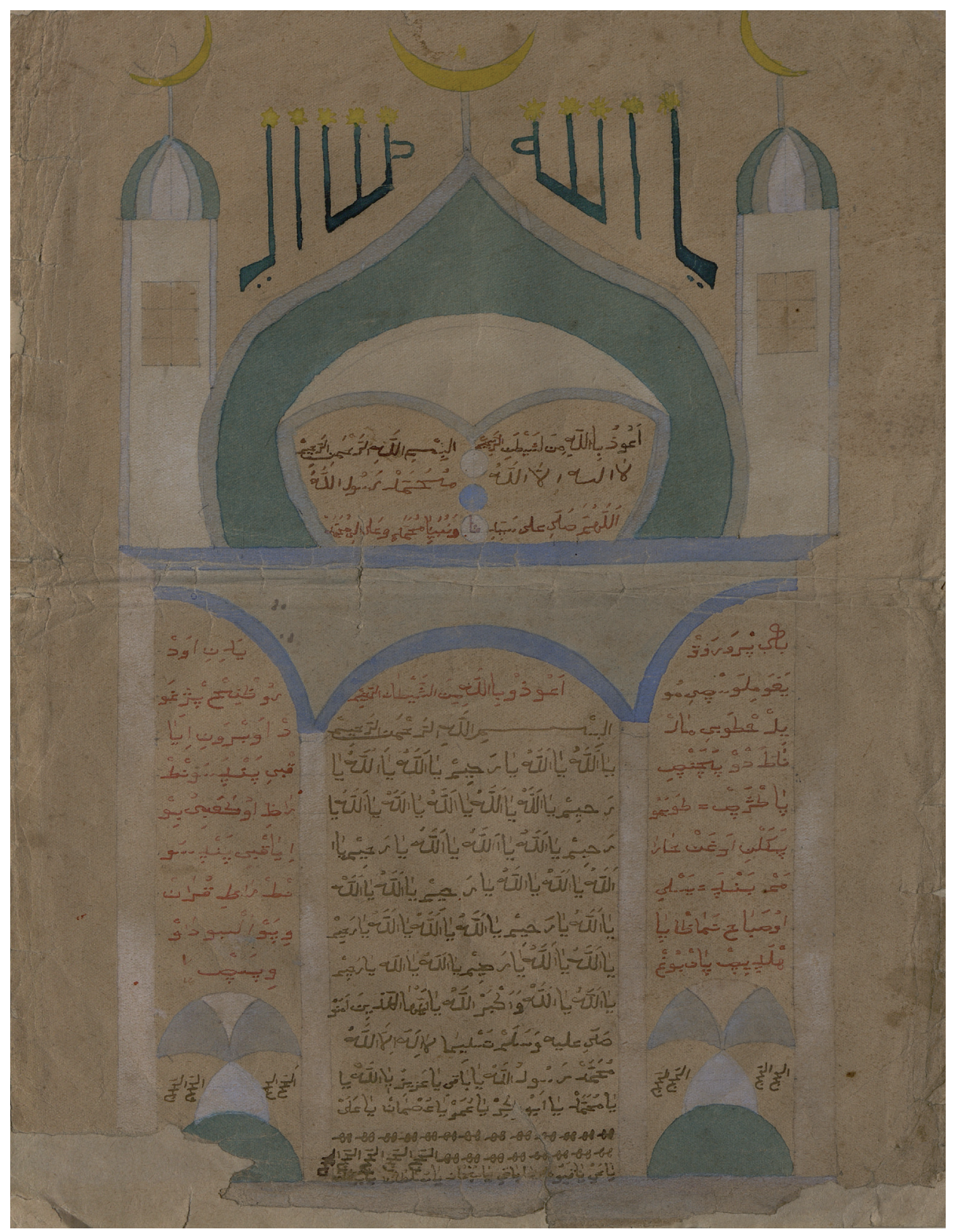

Fot. 3. Muhir Dawida Mucharskiego, 1854 r. (zbiory Muzeum Historycznego w Białymstoku, $\mathrm{MBH} / 1115$, fot. M. Węcław)

Do rękopiśmiennych zabytków związanych z obrzędowością religijną Tatarów polsko-litewskich można także zaliczyć:

1. Dywanik modlitewny, pocz. XX w., 116,0 x 79,5 cm. Został wykonany z zielonej tkaniny i obszyty żółtymi frędzlami. Pod wyhaftowanymi gwiazdą i półksiężycem widnieje inskrypcja w języku arabskim: „Nie ma Boga prócz Allaha”. Odnaleziono go na strychu me- 
czetu w Bohonikach w bardzo złym stanie zachowania (częściowo zetlały, wyblakły, z ubytkami) (MBH/1119);

2. Całun pogrzebowy, 112,0 x 240,0 cm, wykonany z czarnego sukna. W środkowej części zostały wyhaftowane żółtą nicią alfabetem arabskim inskrypcje, z których odczytano jedynie szahadę. Na dole umieszczono zapisane łacinką inicjały „M. A.” i datę: „5 VIII / 1932 roku" $(\mathrm{MBH} / 1117)$.

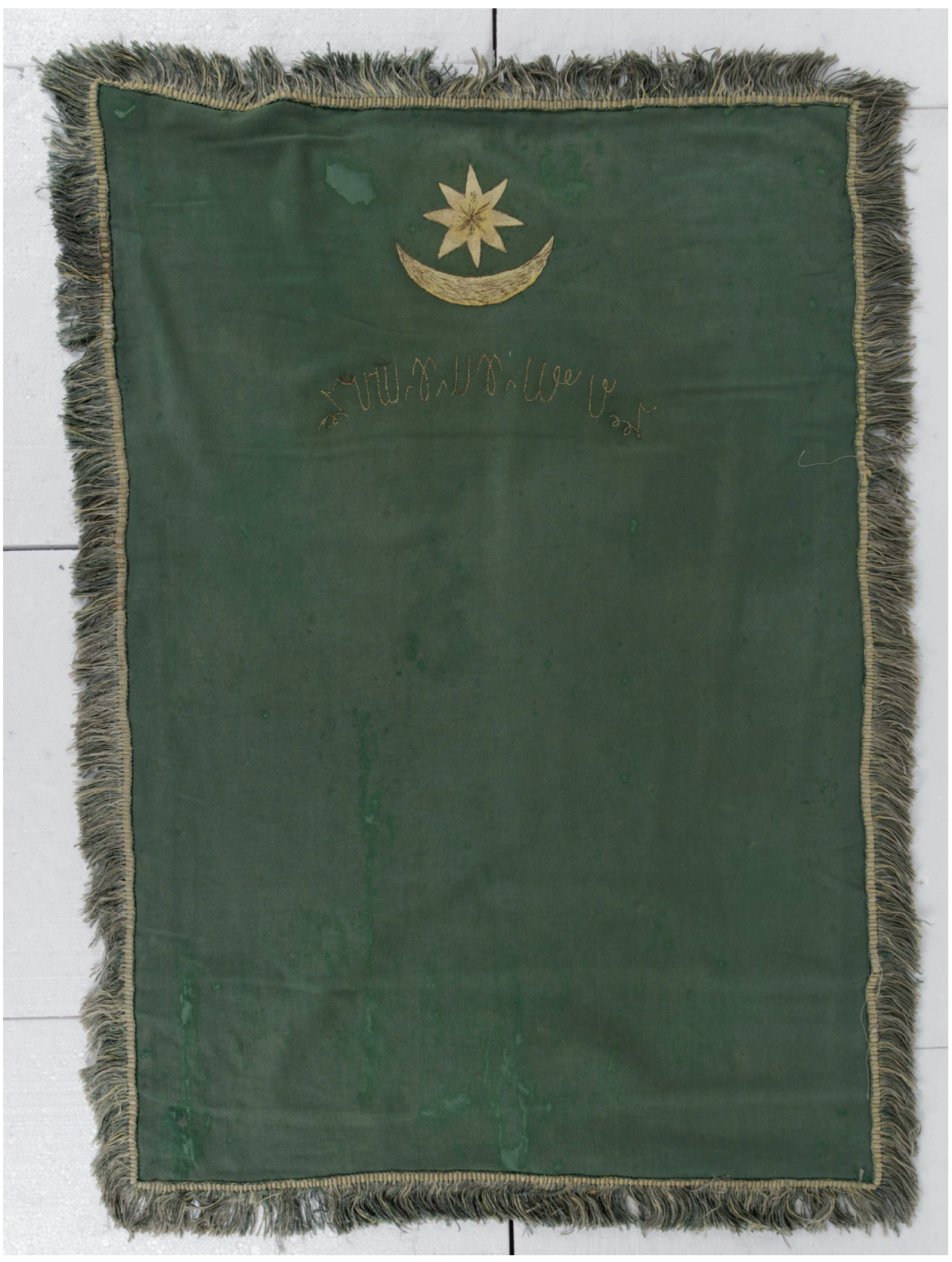

Fot. 4. Muzułmański dywanik modlitewny z Bohonik (zbiory Muzeum Historycznego w Białymstoku MBH/1119, fot. K. Besztak) 
Rękopiśmienne zabytki sięgają XIX w., i to one głównie świadczą o zakorzenieniu Tatarów w historii Polski. Ale do zbiorów trafily także Korany i muhiry rękopiśmienne oraz drukowane, importowane $\mathrm{z}$ krajów muzułmańskich, ale funkcjonujące $\mathrm{w}$ tutejszym środowisku. Z końca XIX w. pochodzą dwa identyczne muhiry z drukarni uniwersyteckiej w Kazaniu. Są to plansze o wymiarach 73,0 x $59,0 \mathrm{~cm}$ z modlitwami i przedstawieniami świętych przedmiotów należących do Proroka, takich jak: grzebień, laska, buty, mata, dzbanek. W górnej części znajduje się rodzaj winiety z wypisanych ozdobną kaligrafią imion: Muhammad oraz Ali (czwarty kalif). Tekst jest ułożony w trzech kolumnach i wpisany także w tarczach i kołach oraz ozdobnikach $(\mathrm{MBH} / 1105,1106)$. Drukowane w Kazaniu Korany pochodzą z pocz. XX w. (MBH/1127, MBH/5296).

W zbiorach znajdują się także importowane $\mathrm{z}$ Turcji dwa rękopiśmienne muhiry z kompozycją kaligraficzną szahady $(\mathrm{MBH} / 1108, \mathrm{MBH} / 1113)$ oraz cztery muhiry drukowane $(\mathrm{MBH} / 1109,1110,1111,1543)$, a także trzy drukowane Korany $(\mathrm{MBH} / 1123$, 1124, 1125).

Z obrzędowością są również związane: strój (rodzaj sutanny) $(\mathrm{MBH} / 1082)$ i nakrycie głowy imama Luta Muchli (MBH/1112), fotografie z muzułmańskiego pogrzebu w Słonimiu z lat 30. XX w. z prowadzącym ceremonię imamem Kemberem Smolskim ${ }^{49}$ (MBHI/7641) oraz z pogrzebu na mizarze (cmentarzu) w Kruszynianach z imamem Aleksandrem Bajraszewskim ${ }^{50}(\mathrm{MBH} / \mathrm{I} / 11859-11862)$.

Wojskowe tradycje kontynuowali Tatarzy $\mathrm{w}$ zmieniających się warunkach historycznych, również w armii carskiej w okresie rozbiorów, po odzyskaniu przez Polskę niepodległości, a także po 1945 r. Ilustrują je dokumenty Bekira ${ }^{51}$ i Henryka ${ }^{52}$ Biciutków (MBH/D/1450-1460), a losy polskich żołnierzy, w tym także Tatarów, w latach II wojny światowej - dokumenty oraz fotografie związane z Aleksandrem Aleksandrowiczem ${ }^{53}$ (MBH/D/7500-7507, MBH/I/7614-7638). Do tradycji wojskowych odnosi się również gipsowa płaskorzeźba przedstawiająca jeźdźca na koniu, wykonana na podstawie rysunku z 1660 r. $(\mathrm{MBH} / 1118)^{54}$.

$\mathrm{Z}$ rodzinnego archiwum tatarskiej rodziny Aleksandrowiczów z Białegostoku do zbiorów muzeum trafily fotografie Macieja i jego synów: Aleksandra, Tymoteusza

49 Kember Smolski był imamem Muzułmańskiej Gminy Wyznaniowej w Słonimiu od 1929 r. i w okresie Il wojny światowej.

50 Aleksander Bajraszewski był imamem Muzułmańskiej Gminy Wyznaniowej w Kruszynianach w latach 1955$-1976$.

51 Bekir Biciutko (1872-1934) - dyplomowany lekarz weterynarii, pułkownik armii rosyjskiej, major WP. W wojsku rosyjskim służył jako lekarz weterynarii Straży Granicznej, następnie jako rejonowy lekarz weterynarii w Obwodzie Twerskim na Kaukazie. Odbył kampanię I wojny światowej. Po wojnie był miejskim lekarzem weterynarii i ordynatorem Szpitala Koni nr 3 w Białymstoku.

52 Henryk Biciutko (1905-1955) - dyplomowany lekarz weterynarii, asystent w klinice chorób wewnętrznych Wydziału Weterynarii Uniwersytetu Warszawskiego. Od 1944 r. służył w WP jako komendant szpitala weterynaryjnego zakaźnego, a następnie jako epizootiolog w sztabie II okręgu wojskowego i szef weterynarii Dowództwa Okręgu Wojskowego Pomorze w stopniu majora lekarza weterynarii. W 1950 r. przeszedł do rezerwy i rozpoczął pracę jako wykładowca w Zespole Techników Rolniczych w Bydgoszczy.

53 Aleksander Aleksandrowicz urodził się 20 lutego 1920 r. w Kajdanowie (pow. miński). 1 września 1937 r. został przyjęty do Podoficerskiej Szkoły Piechoty dla Małoletnich nr 2 w Śremie, którą ukończył w 1939 r. Brał udział w kampanii wrześniowej jako dowódca drużyny. Został wzięty do niewoli 13 września 1939 r. i przebywał w obozie jenieckim nr 140 w Gustedt. Po zakończeniu wojny pozostał w Niemczech i pracował w kopalni. Do Polski wrócił w 1962 r. i mieszkał w Białymstoku.

54 „Rotmistrz tatarski podług malowidła z 1660 r. według ryciny z dzieła Tadeusza Korzona”, „Dzieje wojen i wojskowości w Polsce" 1923, t. 2. 
i Konstantego. Maciej w 1904 r. pracował w Urzędzie Akcyz w Kobryniu ${ }^{55}$. Tymoteusz Aleksandrowicz urodził się w 1882 r., szkołę ukończył w Święcianach. W 1900 r. dostał przydział do pracy w Państwowym Banku Rosji Oddział w Białymstoku, w którym pracował na stanowisku pomocnika buchaltera ${ }^{56}$. Konstanty - najmłodszy syn Macieja i Halimy, skończył Szkołę Realną w Białymstoku. Następnie studiował w Państwowym Instytucie Politechnicznym im. Piotra Wielkiego w Sankt-Petersburgu. Był członkiem nielegalnie działającego w Petersburgu w latach 1907-1910 „Koła Akademików-Muzułmanów Polskich”57 (MBH/I/1683-1690). Z ich zbiorów pochodzą także: „Odezwa dowódcy Szwadronu Ułanów Tatarskich rotmistrza Aleksandra Jeljaszewicza"58, wydana w Wilnie w 1938 r., wzywająca Tatarów do finansowego wsparcia Szwadronu Tatarskiego 13 Pułku Ułanów Wileńskich (MBHD/2665), dwie ulotki omawiające zawartość drugiego i trzeciego tomu Rocznika Tatarskiego - wydawnictwa Centralnej Rady Związku Kulturalno-Oświatowego Tatarów RP (MBHD/2666, 2667) oraz potwierdzenia dla Tymoteusza Aleksandrowicza wpłaty na „Przegląd Islamski”. Był to organ prasowy Muzułmańskiej Gminy Wyznaniowej w Warszawie, której przewodniczącym w latach 1933-1937 był Olgierd Najman Mirza Kryczyński $^{59}$ (MBH/D/2636-2637).

55 Pamiatnaja kniżka Grodnienskoj guberni na 1904 god, Grodna 1904 год, s. 246.

56 Pamiatnaja kniżka Grodnienskoj guberni na 1910 god, Grodna 1910, s. 19.

57 „Rocznik Tatarski” 1935, t. 2, Zamość, s. 76.

58 Aleksander Jeljaszewicz (1902-1978) - major kawalerii WP. W latach 1912-1919 był słuchaczem Korpusu Kadetów w Pskowie, a następnie w Kijowie. Ewakuowany do Turcji i Jugosławii, gdzie w 1923 r. ukończył oficerską szkołę kawalerii. Do 1925 pełnił służbę w serbskiej straży granicznej, po czym powrócił do Polski. W 1925 r. został przyjęty do Wojska Polskiego, w którym rozpoczął naukę w Oficerskiej Szkole Kawalerii w Grudziądzu. Zawodową służbę wojskową rozpoczął w stopniu ppor. w 1928 r. w 4 Pułku Ułanów Zaniemeńskich stacjonującym w garnizonie Wilno. W październiku 1938 r. został przeniesiony do 13 Pułku Ułanów Wileńskich w garnizonie Nowa Wilejka, w którym objałł dowództwo 1 Szwadronu Ułanów Tatarskich, ostatniego pododdziału jazdy tatarskiej w historii Rzeczypospolitej. W 1939 r. brał udział w kampanii wrześniowej. Dostał się do niewoli niemieckiej i resztę wojny spędził w oflagu. Zob. Z. Kosztyła, Szwadron Ułanów Tatarskich, „Wojskowy Przegląd Historyczny” 1986, nr 4 (118), s. 209.

59 Olgierd Najman Mirza Kryczyński herbu Radwan (1884-1941) - urodzony w rodzinie generała Konstantego Kryczyńskiego, brat Leona Kryczyńskiego. W latach 1903-1908 studiował prawo na uniwersytecie w Petersburgu, gdzie był jednym z inicjatorów założenia w 1907 r. koła studentów muzułmańskich. W latach 1919-1920 uczestniczył w narodowo-wyzwoleńczym ruchu na Krymie i w Azerbejdżanie. Wiosną 1920 r. wrócił do Wilna. Zawodowo związał się z wymiarem sprawiedliwości, m.in. pełnił funkcję prokuratora Sądu Okręgowego w Wilnie. Był jednym ze współzałożycieli Związku Kulturalno-Oświatowego Tatarów RP utworzonego w 1925 r. Od grudnia 1928 r. do początków wojny był przewodniczącym Rady Centralnej Związku. W latach 1933-1937 przewodniczył warszawskiej muzułmańskiej gminie wyznaniowej, a w latach 1938-1939 był członkiem Prezydium Najwyższego Kolegium Muzułmańskiego Związku Religijnego. Aresztowany przez NKWD 15 lutego 1941 r., został rozstrzelany 2 czerwca 1941 r. Zrehabilitowany pośmiertnie 24 grudnia 1989 r. Zob. S. Dumin, A. Jakubauskas, G. Sitdykow, op. cit., s. 100-101. 


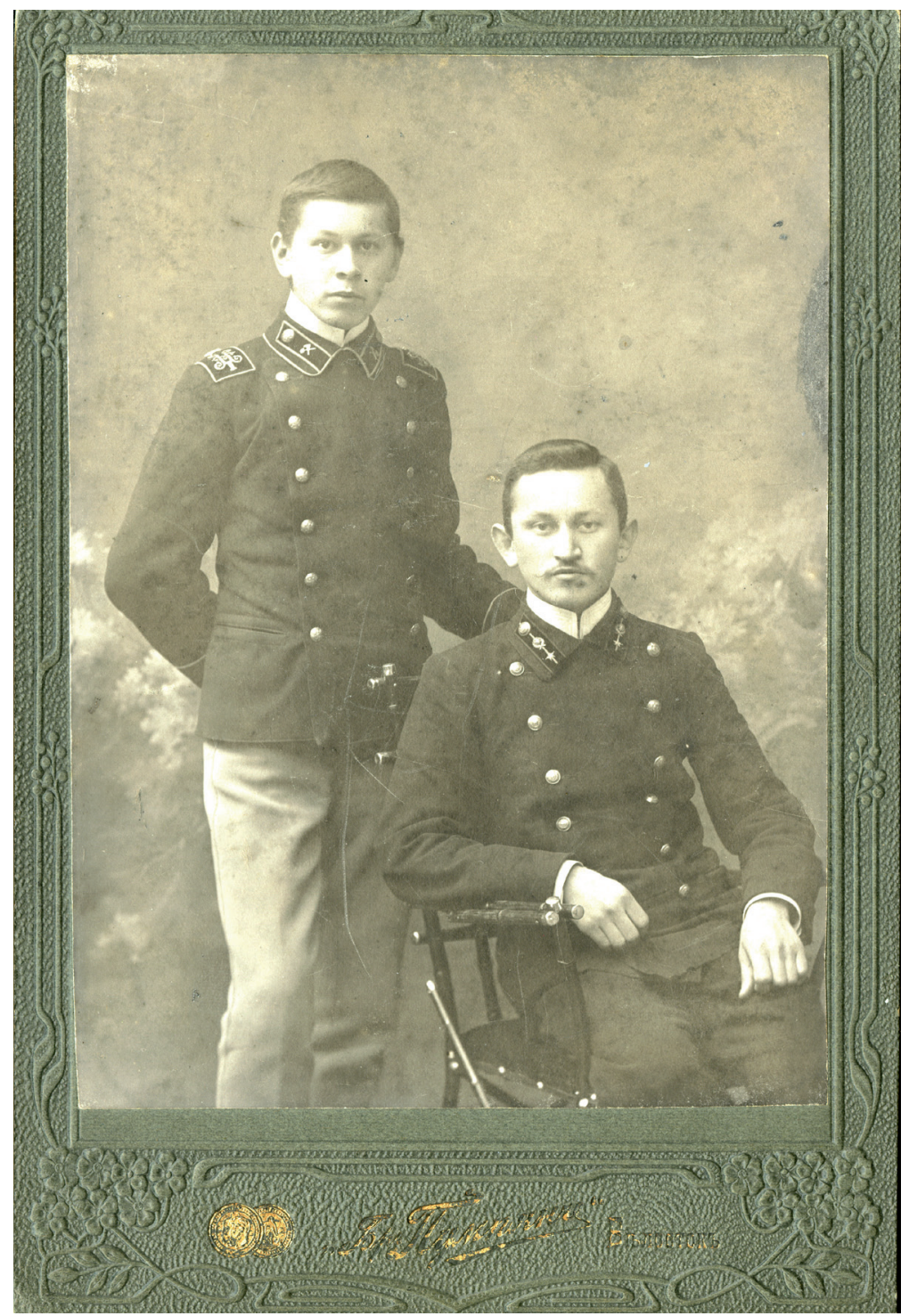

Fot. 5. Tymoteusz i Konstanty Aleksandrowiczowie (zbiory Muzeum Historycznego w Białymstoku, MBH/I/1684, fot. M. Malinowska)

Zbiorem pamiątek podarowanych przez Olgę Piotrowicz ${ }^{60}$ do kolekcji „tatarianów” są fotografie i dokumenty związane $\mathrm{z}$ historią jej rodziny. Najstarsze zdjęcia, z lat 1905-1910, przedstawiają rodzinę Bohdanowiczów w ich domu w Wilnie. To posiadłość dziadków Olgi Piotrowicz - Bury (pułkownika armii carskiej) i Olgi Bohdanowiczów. Na fotografiach można zobaczyć także ich córkę Helenę, matkę Olgi (MBH/I/3878, 3879, 3880).

60 Olga Piotrowicz (1919-2009) - urodziła się w Wilnie, gdzie studiowała na Wydziale Sztuk Pięknych Uniwersytetu Stefana Batorego. Po 1945 r. zamieszkała w Toruniu i ukończyła Wydział Sztuk Pięknych UMK; malarka, architektka wnętrz. Zob. Encyklopedia Ziemi Wileńskiej. Sztuka. Malarze, rzeźbiarze, graficy, fotograficy, Bydgoszcz 2005, s. 173. 
Helena Bohdanowicz ukończyła w 1902 r. Aleksandryjsko-Maryjski Instytut Wychowania Panien w Warszawie (MBH/D/5116). Kolejne fotografie przedstawiają wizytę prezydenta Ignacego Mościckiego w meczecie w Wilnie 20 czerwca 1930 r. W „Kronice” I tomu „Rocznika Tatarskiego” w opisie z uroczystości czytamy: „Przed meczetem powitał Pana Prezydenta zarząd miejscowej gminy muzułmańskiej z generałem Aleksandrem Romanowiczem ${ }^{61}$ na czele, a dziewczynki muzułmańskie wręczyły Wysokiemu Gościowi kwiaty. Po wejściu Wysokiego Dostojnika do meczetu imam Ibrahim Smajkiewicz ${ }^{62}$ odprawił modły...”63. Jedną z dziewczynek była Olga Piotrowicz (MBH/I/3873-3875). Dopełnieniem tego wątku jest zaproszenie dla Włodzimierza i Heleny Piotrowiczów, rodziców Olgi, na tę uroczystość (MBH/D/7507).

Do zbiorów został również przekazany rysunek fragmentu cmentarza muzułmańskiego w Wilnie, sygnowany na odwrocie: Olga Piotrowicz Vilnius 1945 - czerwiec (MBH/2320).

W kolekcji znajdują się również fotografie niektórych meczetów, ale najbogatsza ikonograficznie jest plansza zatytułowana Rozmieszczenie osiedli muzutmańskich na ziemiach Polski, Litwy i Białorusi. Jej autor Ali Smajkiewicz ${ }^{64} \mathrm{w}$ obramowaniu mapy zamieścił rysunki 19 świątyń muzułmańskich rozmieszczonych na pograniczu Litwy i Polski (MBH/1040).

Muzeum Historyczne Oddział Muzeum Podlaskiego w Białymstoku, posiadając w swoich zbiorach niepowtarzalną i największą w skali kraju kolekcję tatarianów, w pełni rozumie szczególną odpowiedzialność za powierzone mu zabytki. Obiekty składające się na ten zbiór wymagają przechowywania i eksponowania zgodnego z zasadami postępowania z zabytkami wytworzonymi na podłożu papierowym i z tkaninami. Muzeum pozyskało z dotacji Ministerstwa Kultury i Dziedzictwa Narodowego środki na pełną konserwację czterech, najcenniejszych w kolekcji, rękopiśmiennych ksiąg religijnych. Gromadzenie wiedzy o wartościach i treściach zawartych w zabytkach jest w przypadku tatarianów trudne ze względu na ich specyficzny zapis. Opracowanie filologiczne manuskryptów powierzono wąskiemu gronu, wyspecjalizowanych w odczytywaniu skomplikowanych językowo tekstów, orientalistów i slawistów. Tatariana były prezentowane na wielu ekspozycjach czasowych w placówkach muzealnych w Polsce. W 2015 r. zostały zdigitalizowane i udostępnione na stronie internetowej Muzeum Podlaskiego w Białymstoku w Muzeum Cyfrowym.

\footnotetext{
61 Aleksander Romanowicz (1817-1933) - generał-major wojsk rosyjskich i generał brygady Wojska Polskiego, dowódca Pułku Tatarskiego Ułanów im. Mustafy Achmatowicza od 3 lutego do kwietnia 1920 r. W 1921 r. został zwolniony do rezerwy i zamieszkał w Wilnie. Przez pięć lat kierował wileńską muzułmańską gminą religijną.

62 Ibrahim Smajkiewicz (1879-1953) - imam wileński od 1921 r., współinicjator powstania Muzułmańskiego Związku Religijnego RP.W 1946 r. osiedlił się z rodziną w Gdańsku i pozostał imamem wspólnoty muzułmańskiej, która wyemigrowała z Wilna. Zob. S. Dumin, A. Jakubauskas, G. Sitdykow, op. cit., s. 147.

63 "Rocznik Tatarski” 1932, t. 1, s. 321.

${ }^{64}$ Ali Smajkiewicz - zmarły w Gdańsku w 1976 r., znawca rękopiśmiennych ksiąg muzułmańskich, autor podręcznika do nauki religii Tadžwîd - Nauka czytania Koranu wydanego w języku polskim w Sarajewie w 1935 r. Zob. U. Wróblewska, Oświata Tatarów w Drugiej Rzeczypospolitej, Warszawa 2012, s. 67.
} 


\section{Bibliografia}

„Ateneum Wileńskie”, r. VII, z. 1/2, Wilno: Towarzystwo Przyjaciół Nauk w Wilnie, 1930.

Berger Rafał, Maciej (Musa) Konopacki. Udręczenie tatarskością, Bydgoszcz: Stowarzyszenie Jedności Muzułmańskiej. Instytut Muzułmański, 2013.

Berger Rafał (red.), Profesorowie do Macieja, Warszawa: Stowarzyszenie Jedności Muzułmańskiej, 2015.

Danecki Janusz, Kultura islamu. Stownik, Warszawa: Wydawnictwa Szkolne i Pedagogiczne, 1997.

Drozd Andrzej, Dziekan Marek, Majda Tadeusz, Katalog Zabytków Tatarskich, t. 3: Piśmiennictwo i muhiry Tatarów polsko-litewskich, Warszawa: Res Publica Multiethnica, 2000.

Dumin Stanisław, Herbarz rodzin tatarskich Wielkiego Księstwa Litewskiego, Gdańsk: Związek Tatarów Rzeczypospolitej Polskiej, 2006.

Dumin Stanisław, Jakubauskas Adas, Sitdykow Galim, Tatarskie biografie. Tatarzy polsko-litewscy w historii i kulturze, Białystok: Muzułmański Związek Religijny w RP, 2012.

Dziadulewicz Stanisław, Herbarz rodzin tatarskich, Wilno: b.n.w., 1929.

Jankowski Henryk, Łapicz Czesław (red.), Klucz do raju. Księga Tatarów litewsko-polskich z XVIII wieku, Warszawa: Wydawnictwo Akademickie Dialog, 2000.

Koran, tłum. Józef Bielawski, Warszawa: Państwowy Instytut Wydawniczy, 1986.

Jackiewicz Mieczysław, Encyklopedia Ziemi Wileńskiej. Sztuka. Malarze, rzeźbiarze, graficy, fotograficy, Bydgoszcz: Towarzystwo Miłośników Wilna i Ziemi Wileńskiej, 2005.

Kosztyła Zygmunt, Szwadron Ułanów Tatarskich, „Wojskowy Przegląd Historyczny” 1986, nr 4 (118).

Kryczyński Stanisław, Tatarzy litewscy. Próba monografii historyczno-etnograficznej, „Rocznik Tatarski” 1938 , t. 3.

Malarczyk Dorota, Między Wschodem a Zachodem. Od Damaszku do Andaluzji. Pieniądz islamski w wiekach średnich, Kraków: Muzeum Narodowe w Krakowie, 2015.

Miśkiewicz Ali, Tatarzy polscy 1918-1939, Warszawa: Państwowe Wydawnictwo Naukowe, 1990.

Obwieszczenie Marszatka Sejmu Rzeczypospolitej Polskiej z dnia 27 lipca 2012 r.w sprawie ogtoszenia jednolitego tekstu ustawy o muzeach, „Dziennik Ustaw Rzeczypospolitej Polskiej” 2012, poz. 987.

Pamiatnaja knizkka Grodnienskoj guberni na 1904 god, Grodna 1904.

Pamiatnaja knizka Grodnienskoj guberni na 1910 god, Grodna 1910.

Radziszewska Iwona, Chamaity jako typ piśmiennictwa religijnego muzutmanów Wielkiego Księstwa Litewskiego (na podstawie stowiańskiej warstwy językowej), niepublikowana praca doktorska, napisana pod kierunkiem prof. Czesława Łapicza, obroniona w 2010 r., UMK, Toruń.

„Rocznik Tatarski” 1932, t. 1.

„Rocznik Tatarski” 1935, t. 2.

Wróblewska Urszula, Oświata Tatarów w Drugiej Rzeczypospolitej, Warszawa: Wydawnictwo Naukowe Semper, 2012. 